\title{
The impact of nitrifying probiotic to population growth of pathogenic bacteria, Vibrio sp., and toxic nitrogen gasses in marine shrimp culture media under laboratory condition
}

\section{Pengaruh probiotik nitrifikasi terhadap pertumbuhan populasi bakteri patogen, Vibrio sp., dan gas nitrogen beracun di dalam media budidaya udang laut pada kondisi laboratorium}

\author{
Bambang Widigdo $^{\mathrm{a}}$, Munti Yuhana ${ }^{\mathrm{b}}$, Aliati Iswantari ${ }^{\mathrm{a}}$, Claritha Madonsa $^{\mathrm{c}}$, Inka Destiana Sapitric, Yusli Wardiatno $^{\mathrm{ae}}$, \\ Agus Alim Hakim ${ }^{\mathrm{a}}$, Fitrina Nazar ${ }^{\mathrm{d}}$

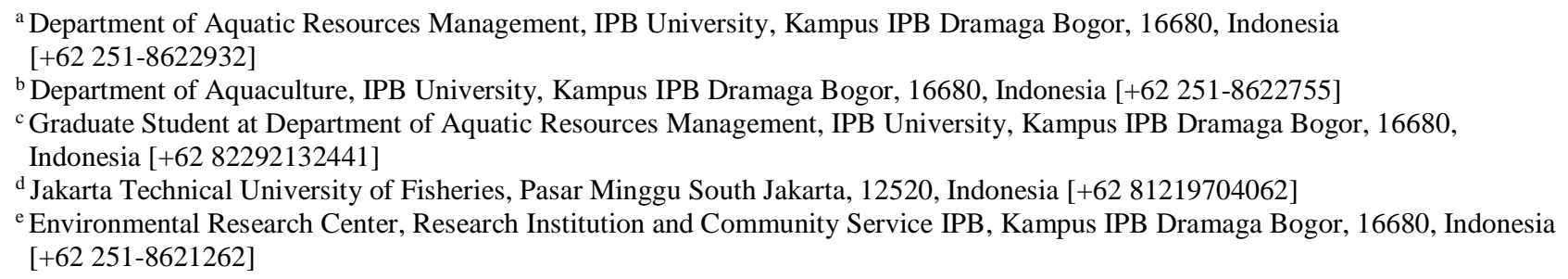

Article Info:

Received: 10 - 02 - 2021

Accepted: $17-03-2021$

Keywords:

Nitrifying, probiotic, toxic, Vibrio

Corresponding Author:

Bambang Widigdo

Department of Aquatic

Resources Management, IPB

University;

Tel.: +62-251-8624360,

Email:

bbg_widigdo@yahoo.co.id

\begin{abstract}
Intensification of shrimp farming has led to problems of water quality and development of pathogenic bacteria. The excess feed and fecal deposited in the bottom of the pond undergo ammonification and result in excess of ammonia formation in pond water and sediment. The purposes of this research were to investigate the impact nitrifying bacteria application on the controlling of pathogenic Vibrio sp. bacteria and toxic nitrogen gasses. Twelve transparent glass bottles (effective volume of $3 \mathrm{~L}$ ) were used in this research. Tested probiotic was purchased in free market and producer claims to contain Nitrosomonas sp., Nitrosococcus sp., Nitrobacter sp., Bacillus sp., Aerobacter sp., and Pseudomonas sp. The tested media was sea water containing Vibrio sp., $\mathrm{TAN}, \mathrm{NO}_{2}$ and $\mathrm{NO}_{3}$ of $54.07 \pm 2.93 \mathrm{mg} / \mathrm{L} ; 6.33 \pm 0.17$ $\mathrm{mg} / \mathrm{L} ; 2.43 \pm 0.04 \mathrm{mg} / \mathrm{L} ;$ and $0.46 \pm 0.01 \mathrm{mg} / \mathrm{L}$ respectively. Treatment of probiotic was $0 \mathrm{mg} / \mathrm{L}$ (control); $0.1 \mathrm{mg} / \mathrm{L} ; 0.2 \mathrm{mg} / \mathrm{L}$; and $0.4 \mathrm{mg} / \mathrm{L}$ with 3 replications. In regard to concentration of Vibrio sp., $\mathrm{NH}_{3}$ and $\mathrm{NO}_{2}$ gasses, treatment doses of $0.1 \mathrm{mg} / \mathrm{L}(A)$ resulted a save level within 4 days after treatment, but to more secure in the practical work for shrimp farm, the doses of $0.2 \mathrm{mg} / \mathrm{L}(B)$ is suggested.
\end{abstract}

How to cite (CSE Style $8^{\text {th }}$ Edition):

Widigdo B, Yuhana M, Iswantari A, Madonsa C, Sapitri ID, Wardiatno Y, Hakim AA, Nazar F. 2021. The impact of nitrifying probiotic to population growth of pathogenic bacteria, Vibrio sp., and toxic nitrogen gasses in marine shrimp culture media under laboratory condition. JPSL 11(1): 130-140. http://dx.doi.org/10.29244/jpsl.11.1.130-140.

\section{INTRODUCTION}

Deteriorating of water quality and increasing pathogenic microorganisms are particularly troublesome in intensive shrimp farm. This condition is a consequence of intensive feeding regime implemented in pond to serve energy for high biomass of shrimp to grow (Mangampa and Suwoyo, 2010). It should be kept in mind that not all feed poured in to pond water consumed by shrimp, at least $15 \%$ of feed would stay eaten less, and 
$20 \%$ of engulfed feed is released back to environment as fecal, metabolite excretion and molting skin (Primavera, 1994). Higher feeding rate will lead to increase left over feed and forms organic sludge accumulate in ponds bottom (Widigdo, 2013). Furthermore Widigdo (2013) described that sludge is producing toxic gasses such as $\mathrm{NH}_{3}$, nitrite $\left(\mathrm{NO}_{2}\right)$, and $\mathrm{H}_{2} \mathrm{~S}$ and potentially a good media for pathogenic microorganism such as Vibrio sp. Old-fashioned method to reduce or eliminate pathogenic microorganism is using chemical such as bactericide, pesticide and antibiotics, which is now strongly not recommended (Atmomarsono et al., 2009). Shrimps farmers wanting to assure the biosecurity of their crops, treatment of probiotic containing nitrifying bacteria is one of the most popular options to reduce organic matter, and furthermore reducing toxic gasses and suppresses the pathogenic microorganisms (Widanarni et al., 2014). Usman and Rochmady (2017) described that nitrifying probiotic is able to improve water quality through reducing organic matter and toxic gasses $\left(\mathrm{NH}_{3}, \mathrm{NO}_{2}\right.$, and $\left.\mathrm{H}_{2} \mathrm{~S}\right)$. Bacteria composing nitrifying probiotic are among others Nitrosomonas sp., Nitrobacter sp., Nitrosococcus sp., Bacillus sp., Aerobacter sp., and Pseudomonas sp., which are capable to oxidize organic matter (Verschuere et al., 2000).

This research aimed to analyze the impact of nitrification probiotic application to improve water quality through reducing Organic matter (BOD) and toxic nitrogen compound (TAN, $\mathrm{NO}_{2}, \mathrm{NH}_{3}$ ), Total Vibrio Count (TVC) includes green and yellow colonies, as well as Total bacterial count (TBC) in laboratorial conditions.

\section{MATERIALS AND METHODS}

The research consisted of preliminary and main researches, and carried out in the laboratory of Aquatic Microbiology, Laboratory of Productivity and Aquatic Environment, Faculty of Fishery and Marine Sciences, IPB University, Bogor, in the period of October until December 2019.

\section{Preliminary Research}

Preliminary research aimed to determine research media composition and determine method in preparing nitrifying probiotic before used to inoculate the research media.

\section{Research Media}

The water media used in this research composed of saline water (salinity of $25 \mathrm{~g} / \mathrm{L}$ ) organic load and total ammonia nitrogen (TAN) approaching to shrimp culture media in the last stage of culture. According to Boyd and Clay (2002), TAN concentration in the last stage of culture would be $5-8 \mathrm{mg} / \mathrm{L}$, and feed doses would around $250 \mathrm{~kg} / \mathrm{day} / 0.36 \mathrm{ha}$. The organic matter was created by adding artificial shrimp feed of $200 \mathrm{mg}$ in to 1 liter of seawater media. To ensure TAN concentration in the media, $46 \mathrm{mg} \mathrm{NH}_{4} \mathrm{Cl}$ was added in to 1 liter media (Saifullah, 2013). The research media (seawater + shrimp feed $+\mathrm{NH}_{4} \mathrm{Cl}$ ) was then incubated in rooms temperature for 24 hours. TAN concentration was analyzed and resulted $10.11 \pm 0.02 \mathrm{mg} / \mathrm{L}$. As this concentration was much higher than expected $(5-8 \mathrm{mg} / \mathrm{L})$, then with the same protocol of preparation, the $\mathrm{NH}_{4} \mathrm{CL}$ concentration was reduced to the half $(23 \mathrm{mg} / \mathrm{L})$, and resulted TAN concentration of $6.34 \mathrm{mg} / \mathrm{L}$. Then, "research media" used for further research consisted of seawater, artificial shrimp feed $(200 \mathrm{mg} / \mathrm{L})$, and $\mathrm{NH}_{4} \mathrm{Cl}$ $(23 \mathrm{mg} / \mathrm{L})$.

\section{Preparing Probiotic}

Nitrifying probiotic used in this research was in powder form and purchased in free market, and producer claims to contain Nitrosomonas sp., Nitrosococcus sp., Nitrobacter sp., Bacillus sp., Aerobacter sp., and Pseudomonas sp. To get advantage of the bacteria it should be activated in a proper manner. Activation media used in this research composes of seawater (salinity $25 \mathrm{~g} / \mathrm{L}$ ), and sugar solution as energy source of bacteria (Juliyanti et al., 2016). Sugar solution was prepared by adding $25 \mathrm{~g}$ of sugar in to $25 \mathrm{ml}$ drinking water (1\% $\mathrm{w} / \mathrm{v}$ ) and mixed properly (Ardiningtyas, 2013). Twenty-five (25) $\mathrm{ml}$ of sugar solution was then transferred in 
to $500 \mathrm{~mL}$ Erlenmeyer, then toped up with seawater to the mark, sterilized in autoclaved, $102^{\circ} \mathrm{C}$ for 1 hour (Novitasari et al., 2017). After it cools to room temperature the media is ready to activation the probiotic cells.

Tested probiotic in the powder was then added to the activation media with a dose of $0.2 \mathrm{mg} / \mathrm{L}$ (as manufacture recommendation. The tested media was equipped with light aeration to ensure oxygen availability and to keep the bacteria in suspension. Total bacteria colony was then analyzed 1 hour after inoculation (as bacterial abundance in T0). Bacterial abundance was then analyzed in interval of 24 hours. The test was ended when the bacterial cells abundance getting decline. The method in calculating the bacterial abundance was performed by following the methods used by Yunita et al. (2015) and Islamey (2019). The result of this preliminary test was used to determine the proper time when the bacterial stage is in the best condition to inoculate in the main research. According to Wulandari et al. (2015), the best condition of transferring bacteria in a new media when the growth start to exponent phase. The preliminary research shows that exponent phase started in 24 hours after incubation (Figure 1). So, for further main research inoculant of bacteria was withdrawn from the bacterial culture 24-48 hours after inoculation.

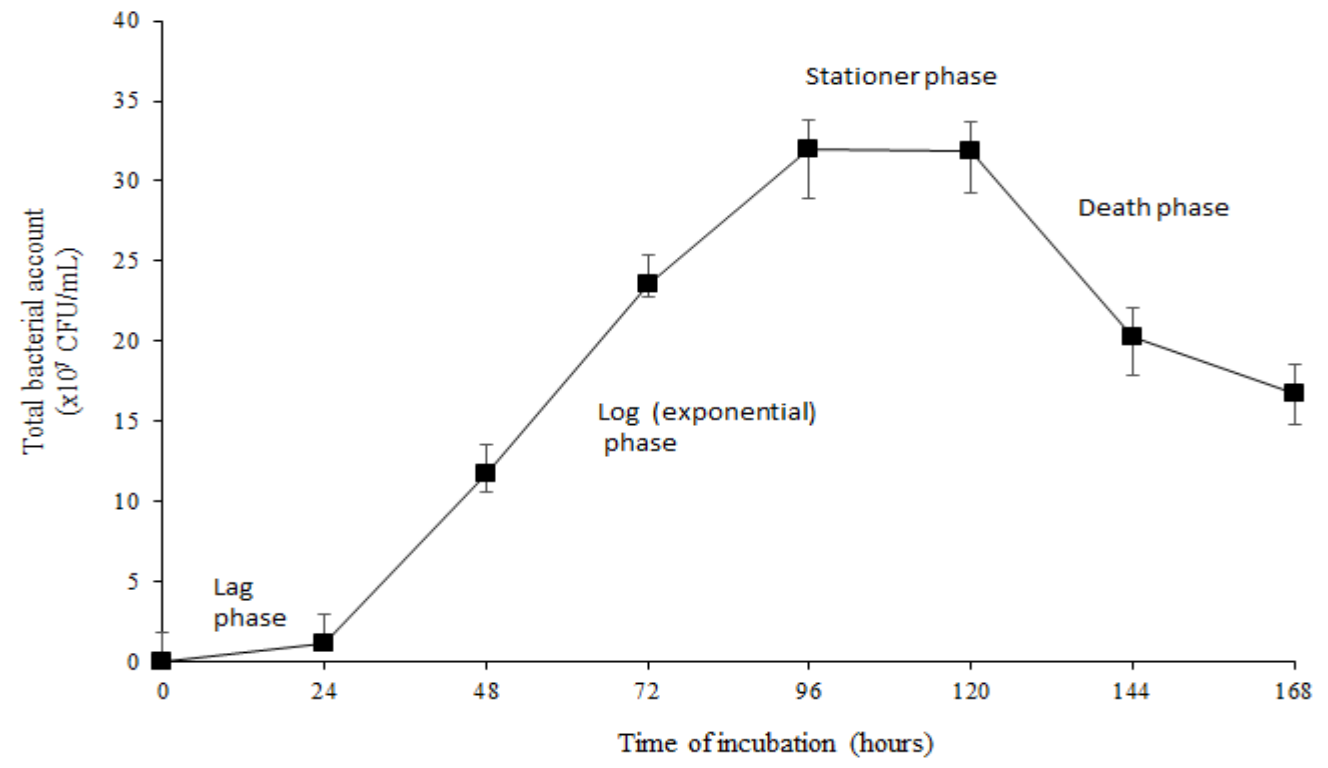

Figure 1 Growth curve of nitrifying bacteria probiotic

\section{Main Research}

The research was designed by using Completely Random Design with 4 treatments and 3 replicates. Twelve (12) transparent glass bottles with capacity of $3 \mathrm{~L}$ were used in this research. Glass containers were filled with $2.5 \mathrm{~L}$ of "research media", and then inoculated with pre-activated probiotic. Four (4) different doses of pre-activated probiotic were inoculated in to the media as treatments (Table 1).

Table 1 Treatment of the research

\begin{tabular}{cccc}
\hline Codes & & Treatments & \\
\hline $\mathrm{K}$ & Seawater media & No probiotic & No probiotic \\
$\mathrm{A}$ & Seawater media & Probiotic $0.1 \mathrm{mg} / \mathrm{L}$ & Pre activated 24 hours \\
B & Seawater media & Probiotic $0.2 \mathrm{mg} / \mathrm{L}$ & Pre activated 24 hours \\
C & Seawater media & Probiotic $0.4 \mathrm{mg} / \mathrm{L}$ & Pre activated 24 hours \\
\hline
\end{tabular}


As resulted in preliminary research, "research media" composed of seawater containing artificial shrimp feed $(200 \mathrm{mg} / \mathrm{L})$, and $\mathrm{NH}_{4} \mathrm{Cl}(23 \mathrm{mg} / \mathrm{L})$ whereas activation media composed $25 \mathrm{ml}$ of sugar solution $(1 \% \mathrm{w} / \mathrm{v})$ added in to $500 \mathrm{ml}$ of seawater. Probiotic cells were pre-activated in the activation media for 24 hours before being inoculated in to media. The containers/treatments were arranged randomly as shown in Figure 2 .

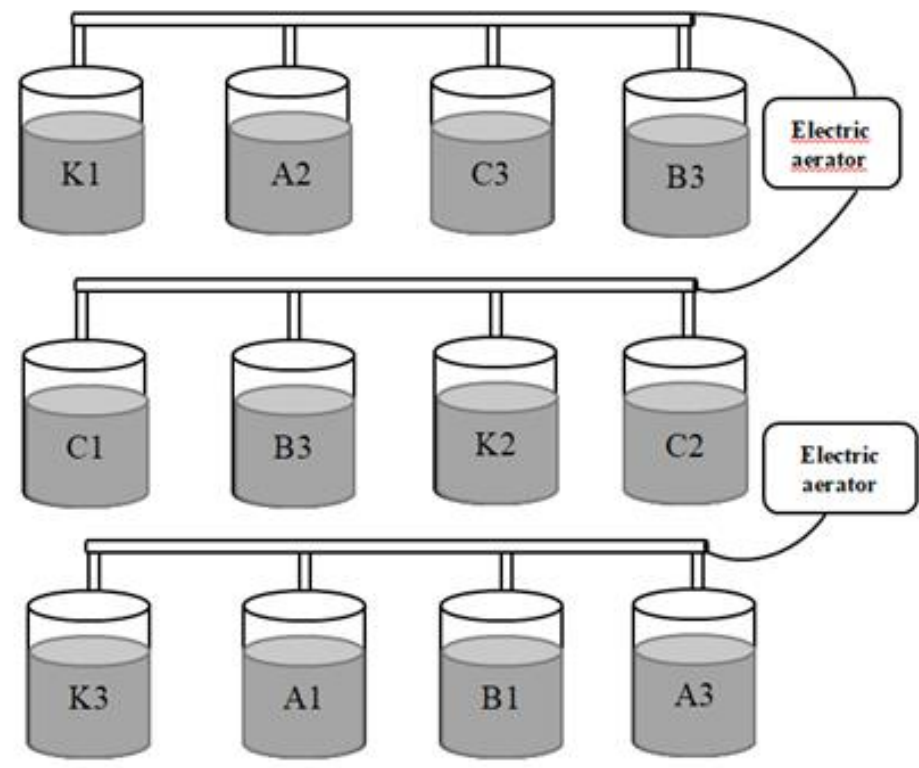

Figure 2 Containers/treatments arrangements (K, A, B and C are treatments code, 1, 2, and 3 are replication)

The same treatments were also performed in 4 separate aquariums (effective volume of 15 Liters). The purpose these treatments were to provide replacement stock treatment as about $600 \mathrm{ml}$ of samples were withdrawn from research container daily. These set of research was arranged in a room temperature of Biomacro Laboratory at Faculty of Fishery and Marine Sciences IPB University.

\section{Parameters Analysis and Samples Withdrawal}

Water quality parameters such as temperature, dissolved oxygen (DO), $\mathrm{pH}$, biological oxygen demand (BOD 5 ), TAN, $\mathrm{NH}_{3}, \mathrm{NO}_{2}, \mathrm{NO}_{3}$, and bacteria analyses were performed daily. Methods and equipment used to analyze are described in Table 2. Bacterial analyses consisted of Vibrio colony (include green and yellow colonies), as well as total bacterial count (TBC).

Table 2 Parameters, methods and equipment used to analysis

\begin{tabular}{ccc}
\hline Parameters & Unit & Method/equipment \\
\hline Temperature & ${ }^{\circ} \mathrm{C}$ & Multiparameter-meter \\
$\mathrm{DO}$ & $\mathrm{mg} / \mathrm{L}$ & DO-meter \\
$\mathrm{BOD}_{5}$ & $\mathrm{mg} / \mathrm{L}$ & $\mathrm{pH}-$ meter \\
$\mathrm{pH}$ & - & Titrimetry \\
$\mathrm{Salinity}$ & $\mathrm{ppt}$ & Refractometer \\
$\mathrm{TAN}$ & $\mathrm{mg} / \mathrm{L}$ & Spectrophotometry \\
$\mathrm{NH}_{3}$ & $\mathrm{mg} / \mathrm{L}$ & Calculated from TAN \\
$\mathrm{NO}_{2}$ & $\mathrm{mg} / \mathrm{L}$ & Spectrophotometry \\
$\mathrm{NO}_{3}$ & $\mathrm{mg} / \mathrm{L}$ & Spectrophotometry \\
Bacteria: & & \\
Total bacteria & $\mathrm{cfu} / \mathrm{ml}$ & Nutrient agar, Total Plate Count (TPC) \\
Total vibrio & $\mathrm{cfu} / \mathrm{ml}$ & TCBSA, Total Plate Count (TPC) \\
\hline
\end{tabular}




\section{Data Analysis}

Data were analyzed descriptively and statistically. Statistical analysis were using SAS (Statistical Analyses Software) version 9.4. If there are a significant different among treatment further analysis using Duncan Multiple Range Test (DMRT) as described by Mattjik and Sumertajaya (2000).

\section{RESULTS AND DISCUSSION}

\section{Results}

There was not any significant changes in $\mathrm{pH}$, temperature, dissolved oxygen (DO), and salinity values. All these parameters were in a good range for aquatic organism (Table 3).

Table 3 Main water quality parameter during the research

\begin{tabular}{ccccc}
\hline & \multicolumn{5}{c}{ Treatments } \\
\hline Parameters & $\mathrm{K}$ & $\mathrm{A}$ & $\mathrm{B}$ & $\mathrm{C}$ \\
\hline \multirow{2}{*}{$\mathrm{pH}$} & 7.14 & 7.05 & 7.25 & 7.34 \\
& $(6.56-7.43)$ & $(6.19-7.50)$ & $(6.09-7.54)$ & $(6.09-7.54)$ \\
\hline \multirow{2}{*}{ Temperature $\left({ }^{\circ} \mathrm{C}\right)$} & 27.2 & 27.4 & 27.2 & 27.1 \\
& $(26.3-27.8)$ & $(26.3-28.3)$ & $(26.3-28.0)$ & $26.3-28.8)$ \\
\hline \multirow{2}{*}{ DO $(\mathrm{mg} / \mathrm{L})$} & 4.2 & 4.1 & 4.1 & 4 \\
& $(2.7-5.6)$ & $(2.7-5.5)$ & $(2.7-5.0)$ & $(2.7-4.8)$ \\
\hline Salinity $(\mathrm{g} / \mathrm{L})$ & 25 & 25 & 25 & 25 \\
\hline
\end{tabular}

\section{Bacterial Population}

Total bacteria population expressed as total bacterial count (TBC) growth in Nutrient Agar revealed an increase with a similar pattern in all treatments (Table 4 and Figure 3). Peak colony of TBC has reached it maximum in day 3 after inoculation, and it dropped down in all treatments. In day 4 after inoculation treatment control $(\mathrm{K})$ indicated significant $(\mathrm{P}<0.05)$ higher population of $\mathrm{TBC}$ compared to treatments $\mathrm{A}, \mathrm{B}$ and $\mathrm{C}$. In day 4, TBC in treatment $\mathrm{A}, \mathrm{B}$ and $\mathrm{C}$ revealed a significant reduction $(\mathrm{P}<0.05)$ compared to day 3 , and is also significant lower compare to control $(\mathrm{K})$ treatment. The TBC in control treatment $(\mathrm{K})$ was $(193.0 \pm 77.0) \times 10^{6}$ $\mathrm{CFU} / \mathrm{mL}$ almost 5 fold compared to all other treatments.

Table 4 Total bacterial account according to treatments

\begin{tabular}{ccccc}
\hline \multirow{2}{*}{ Day } & \multicolumn{4}{c}{ Total Bacteria Count $(\mathrm{TBC})\left(\mathrm{x} 10^{6} \mathrm{CFU} / \mathrm{mL}\right)$} \\
\cline { 2 - 5 } & $\mathrm{K}$ & $\mathrm{A}$ & $\mathrm{B}$ & $\mathrm{C}$ \\
\hline 0 & $0.4 \pm 0.1$ & $0.6 \pm 0.4$ & $0.6 \pm 0.1$ & $0.8 \pm 0.2$ \\
1 & $56.0 \pm 1.8$ & $75.0 \pm 12.0$ & $117.0 \pm 16.3$ & $123.0 \pm 64.1$ \\
2 & $49.0 \pm 7.4$ & $73.0 \pm 21.2$ & $47.0 \pm 4.6$ & $52.0 \pm 1.6$ \\
3 & $234.0 \pm 23.0$ & $229.0 \pm 11.2$ & $157.0 \pm 72.0$ & $214.0 \pm 18.2$ \\
4 & $193.0 \pm 77.0$ & $38.0 \pm 5.7$ & $38.0 \pm 0.4$ & $36.0 \pm 19.4$ \\
\hline
\end{tabular}




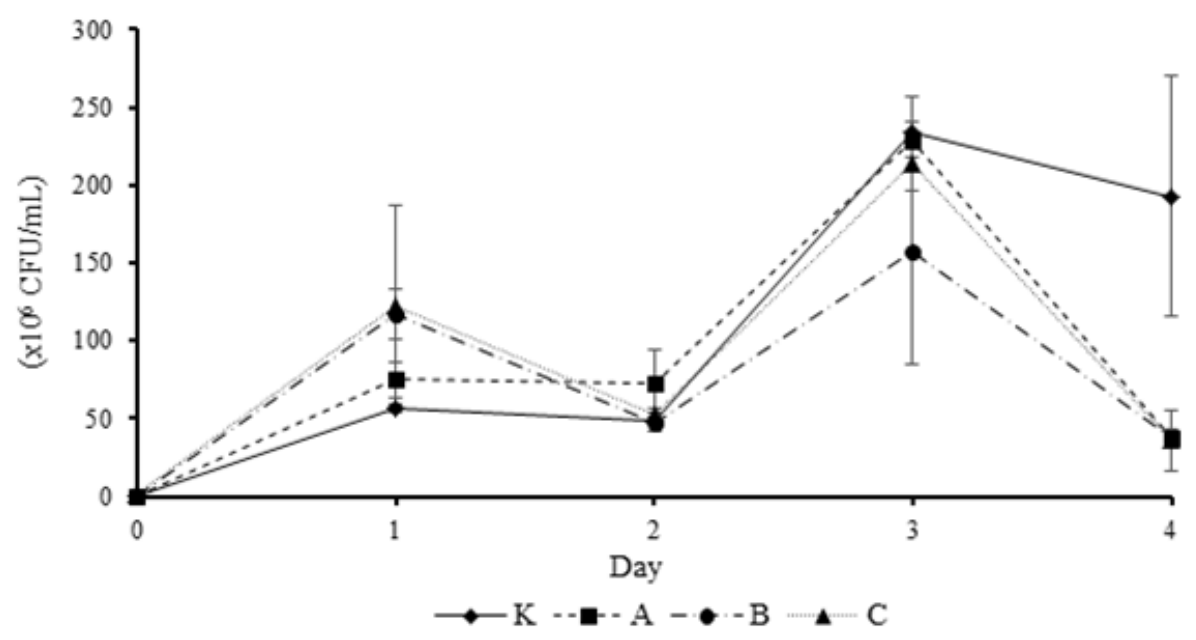

Figure 3 Population growth of total bacteria (TBC)

\section{Vibrio Bacteria}

The population growth of Vibrio expressed as total vibrio count, green and yellow colonies are shown in Table 5, and its pattern is illustrated in Figure 4.

Table 5 Population growth of Vibrio expressed as TVC, green and yellow colony

\begin{tabular}{|c|c|c|c|c|c|c|c|c|}
\hline \multirow{4}{*}{ Day } & \multicolumn{8}{|c|}{ Total Vibrio count $\left(\mathrm{x} 10^{2} \mathrm{CFU} / \mathrm{mL}\right)$ all treatments } \\
\hline & \multicolumn{2}{|c|}{$\mathrm{K}$} & \multicolumn{2}{|c|}{$\mathrm{A}$} & \multicolumn{2}{|c|}{$\mathrm{B}$} & \multicolumn{2}{|c|}{$\mathrm{C}$} \\
\hline & \multicolumn{2}{|c|}{ TVC } & \multicolumn{2}{|c|}{ TVC } & \multicolumn{2}{|c|}{ TVC } & \multicolumn{2}{|c|}{ TVC } \\
\hline & green & yellow & green & yellow & green & yellow & green & yellow \\
\hline \multirow{2}{*}{0} & \multicolumn{2}{|c|}{$24.0 \pm 1.0$} & \multicolumn{2}{|c|}{$26.0 \pm 9.6$} & \multicolumn{2}{|c|}{$15.0 \pm 0.4$} & \multicolumn{2}{|c|}{$15.8 \pm 9.1$} \\
\hline & $9.5 \pm 0.5$ & $14.2 \pm 0.4$ & $11.0 \pm 3.1$ & $15.4 \pm 8.4$ & $4.1 \pm 0.7$ & $10.6 \pm 0.4$ & $5.9 \pm 0.3$ & $9.9 \pm 0.4$ \\
\hline \multirow[b]{2}{*}{1} & \multicolumn{2}{|c|}{$76.0 \pm 16.0$} & \multicolumn{2}{|c|}{$200.0 \pm 45.4$} & \multicolumn{2}{|c|}{$229.0 \pm 90.0$} & \multicolumn{2}{|c|}{$51.0 \pm 14.6$} \\
\hline & $\begin{array}{c}42.0 \pm 2 . \\
5\end{array}$ & $\begin{array}{c}34.0 \pm 11 \\
7\end{array}$ & $68.0 \pm 15.2$ & $\begin{array}{c}132.0 \pm 47 \\
5\end{array}$ & $84.0 \pm 19.8$ & $\begin{array}{c}145.0 \pm 41 \\
9\end{array}$ & $20.0 \pm 3.9$ & $31.0 \pm 13.1$ \\
\hline \multirow[b]{2}{*}{2} & \multicolumn{2}{|c|}{$103.0 \pm 32.6$} & \multicolumn{2}{|c|}{$135.0 \pm 55.0$} & \multicolumn{2}{|c|}{$279.0 \pm 77.6$} & \multicolumn{2}{|c|}{$24.0 \pm 7.0$} \\
\hline & $\begin{array}{c}41.3 \pm 5 . \\
6\end{array}$ & $62.0 \pm 6.0$ & $90.0 \pm 22.3$ & $45.0 \pm 31.8$ & $\begin{array}{c}108.0 \pm 31 \\
4\end{array}$ & $\begin{array}{c}171.0 \pm 65 \\
6\end{array}$ & $18.0 \pm 3.5$ & $6.0 \pm 2.3$ \\
\hline \multirow{2}{*}{3} & \multicolumn{2}{|c|}{$2.3 \pm 1.1$} & \multicolumn{2}{|c|}{$0.7 \pm 0.4$} & \multicolumn{2}{|c|}{$0.3 \pm 0.0$} & \multicolumn{2}{|c|}{$0.1 \pm 0.06$} \\
\hline & $0.7 \pm 0.3$ & $1.6 \pm 1.5$ & $0.2 \pm 0.1$ & $0.5 \pm 0.4$ & $0.1 \pm 0.0$ & $0.2 \pm 0.1$ & $0.0 \pm 0.0$ & $0.1 \pm 0.1$ \\
\hline \multirow[b]{2}{*}{4} & \multicolumn{2}{|c|}{$20.0 \pm 6.5$} & \multicolumn{2}{|c|}{$11.8 \pm 1.9$} & \multicolumn{2}{|c|}{$0.0 \pm 0.0$} & \multicolumn{2}{|c|}{$0.7 \pm 0.4$} \\
\hline & $\begin{array}{c}20.0 \pm 6 . \\
5\end{array}$ & $0.2 \pm 0.1$ & $10.5 \pm 2.6$ & $1.3 \pm 0.5$ & $0.0 \pm 0.0$ & $0.0 \pm 0.0$ & $0.7 \pm 0.1$ & $0.0 \pm 0.0$ \\
\hline
\end{tabular}

The population of Vibrio (TVC) increased in all treatments in day 1, and then indicated different effect of treatments from day 1 to day 2 . The population decreased in treatment $\mathrm{A}$ and $\mathrm{C}$, meanwhile it increased in treatment B and control $(\mathrm{K})$. The maximum TVC of $(2.79 \pm 0.78) \times 10^{4} \mathrm{CFU} / \mathrm{mL}$ was found in treatment B and was significantly higher compared to others. All treatments have led to TVC reduction from day 2 to day 4 to a very low concentration. No more TVC colony were found in treatment $\mathrm{B}$, and only $(0.7 \pm 0.4) \times 10^{2}$ $\mathrm{CFU} / \mathrm{mL}$ and $(1.18 \pm 0.19) \times 10^{3} \mathrm{CFU} / \mathrm{mL}$ observed in treatment $\mathrm{C}$ and $\mathrm{A}$ respectively, and are much lower compared to those in control $(\mathrm{K})$ treatment which was $(2.00 \pm 0.65) \times 10^{3} \mathrm{CFU} / \mathrm{mL}$. 
Green colony was generally lower compared to yellow colony. Out of 5 observation (day 0 to day 4), there were 2 observation in control treatment $(\mathrm{K}, \mathrm{A}$ and $\mathrm{C})$ where green colony was higher than yellow one. Observation in treatment B showed green colony consistently lower than yellow colony.
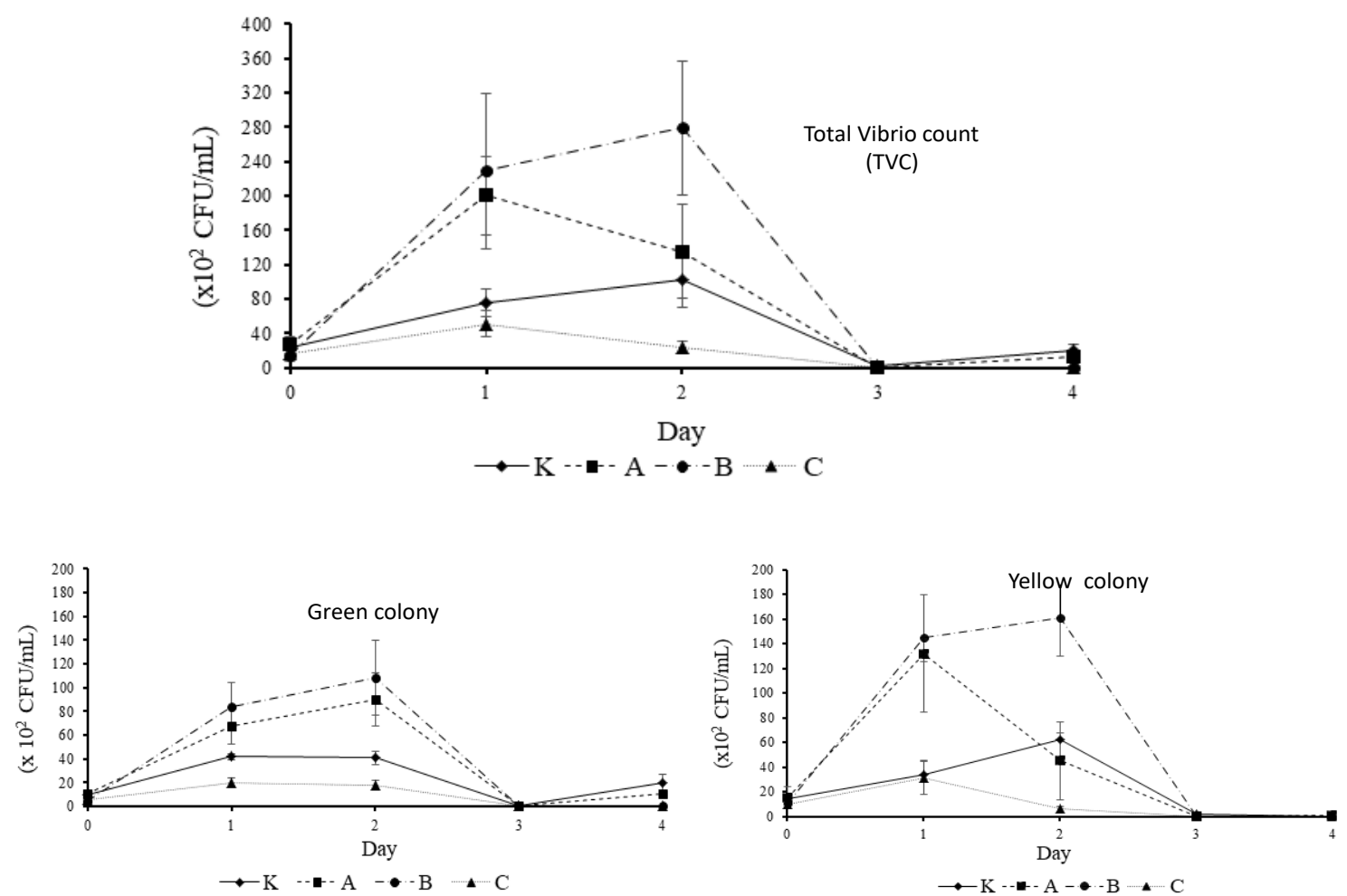

Figure 4 Population growth of Vibrio bacteria as Total Vibrio Count (TVC) green and yellow colonies

\section{$\mathrm{BOD}_{5}$ and Nitrogen Gasses}

Organic matter expressed as $\mathrm{BOD}_{5}$ was reduced significantly $(\mathrm{P}<0.05)$ from day 0 to day 4 in all treatments. Concentration of $\mathrm{BOD}_{5}$ in the day 0 was $54.07 \pm 2.93 \mathrm{mg} / \mathrm{L}$, and was significantly reduced to much lower concentration in all treatment. The concentration dropped down to $17.57 \pm 1.17 \mathrm{mg} / \mathrm{L} ; 18.92 \pm 1.17$ $\mathrm{mg} / \mathrm{L}$ and $17.57 \pm 2.34 \mathrm{mg} / \mathrm{L}$ in day 4 for treatment $\mathrm{A}, \mathrm{B}$ and $\mathrm{C}$ respectively, and were significantly $(\mathrm{P}<0.05)$ greater reduction compared to control (K) with $21.63 \pm 1.17 \mathrm{mg} / \mathrm{L}$ of $\mathrm{BOD}_{5}$ in in day 4 (Figure 5).

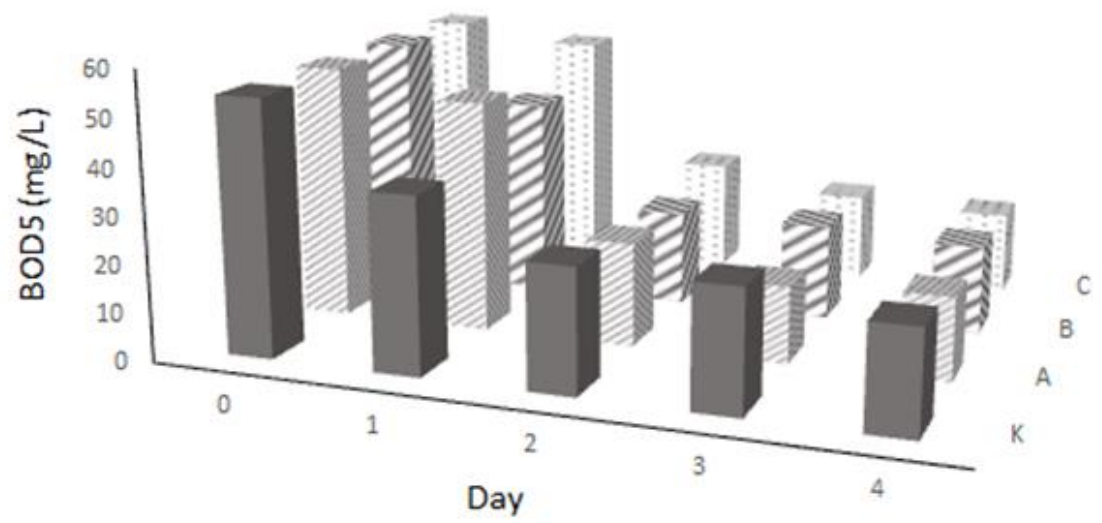

Figure 5 Concentration of $\mathrm{BOD}_{5}$, following probiotic application 
Concentration of TAN, $\mathrm{NH}_{3}, \mathrm{NO}_{2}$, and $\mathrm{NO}_{3}$ following the treatments are illustrated in Figure 6 . In the first day of probiotic inoculation, TAN concentration was $6.34 \pm 0.17 \mathrm{mg} / \mathrm{L}$ and it dropped significantly $(\mathrm{P}<0.05)$ down only within one day (day 1 ) for all treatment. The concentration remained to $0.08 \pm 0.00 \mathrm{mg} / \mathrm{L} ; 0.07 \pm$ $0.00 \mathrm{mg} / \mathrm{L}$ and $0.08 \pm 0.00 \mathrm{mg} / \mathrm{L}$ for treatment $\mathrm{A}, \mathrm{B}$ and $\mathrm{C}$ respectively and slightly higher in not treated water (control K) of $0.09 \pm 0,01 \mathrm{mg} / \mathrm{L}$ in day 4 .

Ammonia $\left(\mathrm{NH}_{3}\right)$ was already very low in the first day after inoculation $(0.10 \pm 0.00 \mathrm{mg} / \mathrm{L})$. This concentration dropped to $\leq 0.03 \mathrm{mg} / \mathrm{L}$ already in day 1 and continuous dropped to $0.00 \mathrm{mg} / \mathrm{L}$ in day 2 to day 4 for all treatments. Nitrite $\left(\mathrm{NO}_{2}\right)$ concentration was $2.44 \mathrm{~L} \pm 0.04 \mathrm{mg} / \mathrm{L}$ in the first day of inoculation. All treatment have led to a fluctuation decrease and reached to minimum value of $1.11 \pm 0.46 \mathrm{mg} / \mathrm{mL}$ (treatment A), $1.20 \pm 0.62 \mathrm{mg} / \mathrm{mL}$ (treatment B), $0.65 \pm 0.02 \mathrm{mg} / \mathrm{L}$ in treatment $\mathrm{C}$ and $0.83 \pm 0.32 \mathrm{mg} / \mathrm{L}$ (control K) in day 4. The different pattern of concentration was shown in $\mathrm{NO}_{3}$, where this parameter increased during 4 days incubation. The concentration of $\mathrm{NO}_{3}$ was $0.46 \pm 0.01 \mathrm{mg} / \mathrm{L}$ in day 0 and increased to $6.9507 \pm 1.8207 \mathrm{mg} / \mathrm{L}$ (treatment A), $8.34 \pm 0.51 \mathrm{mg} / \mathrm{L}$ (treatment B), and $5.4861 \pm 0.4860 \mathrm{mg} / \mathrm{L}$ (treatment C). Slightly lower was found in control $(\mathrm{K})$ treatment of $4.44 \pm 0.27 \mathrm{mg} / \mathrm{L}$.
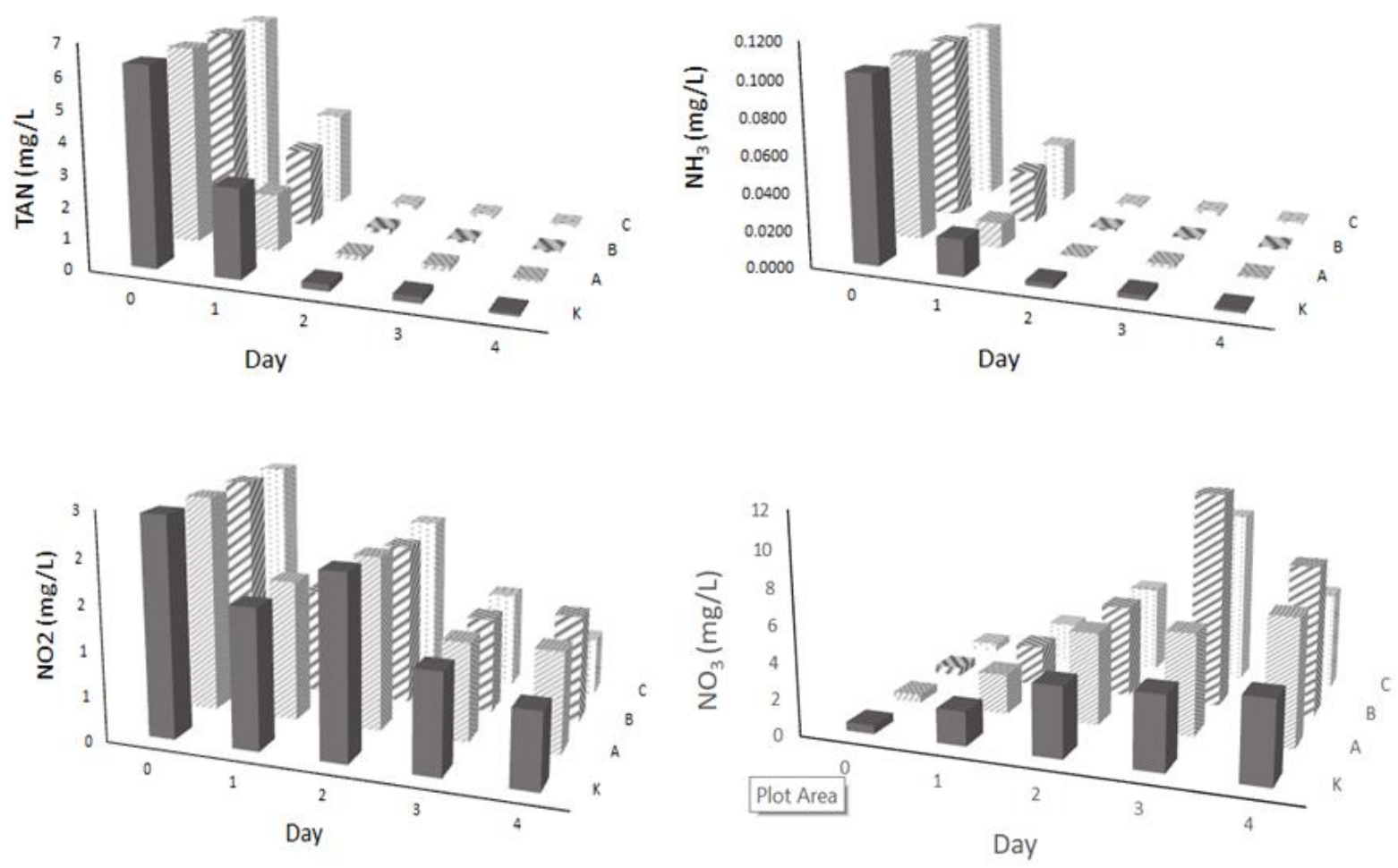

Figure 6 Concentration of nitrogenous compound following application of nitrifying probiotic

\section{Discussion}

Intensive shrimp culture lead to a significant accumulation of organic matter mainly from excess feed and shrimp feces. Uneaten feed and feces are decomposed by bacteria within which organic carbon oxidized to carbon dioxide, and organic nitrogen mineralized to ammonia, nitrite and nitrate (Moriarty, 1999). This will potentially increases pathogenic bacteria and worsen water quality. Population of pathogenic bacteria such as Vibrio sp. will increase as organic load increases (Boyd, 2007; Widigdo, 2013). Nitrifies are chemoautotrophic bacteria which capable to synthesize organic matter through nitrification processes (Boyd, 2007). Nitrification is a natural water purification process by oxidizing potentially toxic ammonia to nontoxic nitrate, and Nitrosomonas and Nitrobacter bacteria play important role in this processes (Karthik et al., 2016). The present 
of nitrifying bacteria is important in aquaculture to maintain the nitrogenous toxic gasses under level of harming the fish or shrimp.

The success of shrimp farming depends upon the maintenance of water quality and the dynamic balance between beneficial and pathogenic bacteria. The use of beneficial bacteria (probiotics) to control or inhibit the pathogenic bacteria by competitive processes is a more efficient disease control strategy and this suggested by many researcher such as Kumar et al. (2016), Karthik et al. (2016), and Jamal et al. (2019).

This research revealed that inoculation of nitrifying bacteria could reduce the organic load in the water. The concentration of $0.1 \mathrm{mg} / \mathrm{L}$ Probiotic (containing Nitrosomonas sp., Nitrosococcus sp., Nitrobacter sp., Bacillus sp., Aerobacter sp., and Pseudomonas sp.) could reduce $68 \%$ of organic matter load (BOD 5 ) within 4 days. Higher doses of 0.2 and $0.4 \mathrm{mg} / \mathrm{L}$ delivered no significant effect. These doses of probiotic resulted the maximum number of total heterotrophic bacteria (TBC) colony of $2.29 \times 10^{8} \mathrm{CFU} / \mathrm{mL}$. This number is close to research conducted by Karthik et al. (2016) where they administered the TBC colony of $1.1 \times 10^{8} \mathrm{CFU} / \mathrm{mL}$ in water containing healthy shrimp larvae, before which the water was inoculated by nitrifying probiotic.

The count of TVC colony was much lower compared to TBC, where the maximum of colony TVC could only reach of $10^{4} \mathrm{CFU} / \mathrm{mL}$ in day 2 . This count would be on the maximum threshold as suggested by Supono et al. (2019). The TVC was event more suppressed to a very low level of $<10^{3}$ when water was treated with nitrifying probiotic. The present of TVC in pond culture is usually creating problem as those bacteria is opportunistic, and causing significant mortality when shrimp in a weak condition (Boyd, 2007). This research confirmed that nitrifying bacteria also present in natural water as TVC in control treatment was also suppressed down to $10^{3} \mathrm{CFU} / \mathrm{mL}$.

Recently farmer still consider green colony as more pathogenic compare to yellow one. Farmer are getting panic if they found green colony in similar number or event greater than yellow colony. Kumar et al. (2016) described that $V$. alginoliticus (yellow colony forming) together with $V$. parahaemoliticus and $V$. vulnificus (both are green colony forming) were responsible for white feces diseases (WFD infected shrimp). Supono et al. (2019) found a similar condition where white feces diseases (WFD) in vannamei shrimp was caused by $V$. alginoliticus and $V$. parahaemoliticus. Zhihong et al. (2018) described that $V$. parahaemoliticus involved in acute hepatopancreatic necrosis disease (AHPND), which causing serious loss shrimp farmer in recent years. So, in this regard it is not any more relevant to differentiate green and yellow colony in the analyses of pathogenic bacteria of Vibrio sp.

This research confirmed that nitrifying probiotic could reduce the concentration of NH3 to $\leq 0.03 \mathrm{mg} / \mathrm{L}$ already in day 1 and dropped continuously to $0.00 \mathrm{mg} / \mathrm{L}$ in day 2 to day 4 event at the lowest treatment of 0.1 $\mathrm{mg} / \mathrm{L}$. This is complying with the guideline given by Wyk and Scarpa (1999). The capacity of nitrifying probiotic to reduce $\mathrm{NO}_{2}$ was also proven in this research. The concentration of $\mathrm{NO}_{2}$ was $\leq 2.50 \mathrm{mg} / \mathrm{L}$ in the first day after inoculation, lower compared to save level as described by Dwiono et al. (2018). Application of nitrifying probiotic has reduced the concentration to $\leq 1.5 \mathrm{mg} / \mathrm{L}$ even though in the lowest doses of probiotic treatment of $0.1 \mathrm{mg} / \mathrm{L}$. In the same salinity as tested in this research $(25 \mathrm{~g} / \mathrm{L})$ save level is $15.20 \mathrm{mg} / \mathrm{L}$. Increment of $\mathrm{NO}_{3}$ during the research period was confirming that bacteria composing probiotic took its important role in oxidizing $\mathrm{NO}_{2}$ (Boyd, 2007). The number of TBC bacteria ware reduced significantly in day 4, (include beneficial bacteria of nitrifying) suggested us to re inoculate the probiotic in a day before to maintain suppressing the TVC growth and nitrogenous gasses concentration maintained under safe level.

\section{CONCLUSION}

Nitrifying Probiotic available in free market which is claimed to compose of Nitrosomonas sp., Nitrosococcus sp., Nitrobacter sp., Bacillus sp., Aerobacter sp., and Pseudomonas sp. is effective to reduce organic matter and suppresses the growth of pathogenic bacteria (TVC) to a save level for shrimp culture. The application doses of $0.1 \mathrm{ml} / \mathrm{L}$ would be sufficient, but $0.2 \mathrm{mg} / \mathrm{L}$ would be more secure. Differentiation among 
green and yellow colonies would not more relevant to evaluate pathogenic bacteria of TVC. Re inoculation of nitrifying probiotic is suggested to maintain TVC growth and nitrogenous gasses maintained under safe level.

\section{REFERENCES}

Ardiningtyas TR. 2013. Pengaruh penggunaan effective microorganism $4\left(\mathrm{EM}_{4}\right)$ dan molase terhadap kualitas kompos dalam pengomposan sampah organik RSUD DR. R. Soetrasno Rembang [skripsi]. Semarang (ID): Universitas Negeri Semarang.

Atmomarsono M, Muliani, Nurbaya. 2009. The using of probiotic bacteria with different compositions to improve water quality and post-larvae survival of tiger shrimp. Jurnal Riset Akuakultur. 4(1): 73-83.

Boyd CE, Clay JW. 2002. Evaluation of belize aquaculture LTD: A superintensive shrimp aquaculture system. Report Prepared under The Word Bank, NACA, and FAO Consortium. Washington DC (US): The Consortium.

Boyd CE. 2007. Nitrification important process in aquaculture. Global Aquaculture Advocate. 10(3): 64-66.

Dwiono A, Widigdo B, Soewardi K. 2018. Pengaruh komposisi mineral air tanah terhadap fisiologi dan histologi udang vaname Litopenaeus vannamei. Jurnal Ilmu dan Teknologi Kelautan Tropis. 10(3): 535546.

Islamey WDN. 2019. Kelimpahan bakteri pada media budidaya dan saluran pencernaan di tambak budidaya udang intensif selama wabah white feces disease [skripsi]. Bogor (ID): IPB University.

Jamal MT, Abdulrahman IA, Harbi MA, Chithambaran S. 2019. Probiotics as alternative control measures in shrimp aquaculture: A review. Journal of Applied Biology \& Biotechnology. 7(3): 69-77.

Juliyanti V, Salamah, Muliani. 2016. The effect of using probiotics in the maintenance medium on goldfish (Carassius auratus) seeds at different ages. Acta Aquatica. 3(2): 66-74.

Karthik R, Pushpam AC, Chelvan Y, Vanitha MC. 2016. Efficacy of Probiotic and nitrifier bacterial consortium for the enhancement of Litopenaeus vannamei aquaculture. Int J Vet Sci Res. 2(1): 1-6.

Kumar V, Roy S, Meena DK, Sarkar UK. 2016. Application of probiotics in shrimp aquaculture: importance, mechanisms of action, and methods of administration, reviews. Fisheries Science \& Aquaculture. 24(4): 342-368.

Mangampa M, Suwoyo S. 2010. Budidaya udang vaname (Litopenaeus vannamei) teknologi intensif menggunakan benih tokolan. Jurnal Riset Akuakultur. 5(3): 351-361.

Mattjik AA, Sumertajaya M. 2000. Design of Experiments with SAS and Minitab Application Volume I. Bogor (ID): IPB Pr.

Moriarty DJW. 1999. Disease control in shrimp aquaculture with probiotic bacteria. In: Bell CR, Brylinsky M, Johnson-Green P, editor. Proceedings of the 8th International Symposium on Microbial Ecol. Canada (US): Atlantic Canada Society for Microbial Ecology.

Novitasari A, Iskandar RN, Elvazia H, Harpeni E. 2017. Provision of Bacillus sp. D2.2 on molasses technique media on water quality and growth performance of vaname shrimp (Litopenaeus vannamei). Biospecies. 10(2): 50-59.

Primavera JH. 1994. Shrimp farming in the Asia-Pacific: environmental and trade issues and regional cooperation. In: Nautilus Institute Workshop on Trade and Environment in Asia-Pacific: Prospects for Regional Cooperation, 1994 Sep 23-25, Honolulu, USA. California (US): Nautilus Institute for Security and Sustainability.

Saifullah. 2013. The role of ammonium chloride $\left(\mathrm{NH}_{4} \mathrm{Cl}\right)$ and sodium nitrite $\left(\mathrm{NaNO}_{2}\right)$ in increasing nitrifying bacteria. Jurnal Ilmu Pertanian dan Perikanan. 22(2): 171-177.

Supono, Wardiyanto, Harpeni E, Annisa H, Khotimah, Ningtyas A. 2019. Identification of Vibrio sp. as cause of white feces diseases in white shrimp Penaeus vannamei and handling with herbal ingredients in East Lampung Regency, Indonesia. AACL Bioflux. 12(2): 417-425. 
Usman A, Rochmady. 2017. Growth and post-tiger survival of shrimp larvae (Penaeus monodon Fabr.) by administering different doses of probiotics. Jurnal Akuakultur, Pesisir dan Pulau-Pulau Kecil. 1(1): 1926.

Verschuere L, Robaut G, Sorgeloos P, Verstraete. 2000. Probiotic bacteria as biological control agents in aquaculture. Microbiology and Molecular Biology. 64(4): 655-671.

Widanarni, Noermala JI, Sukenda. 2014. Provision of prebiotics, probiotics, and synbiotics for the control of co-infection with Vibrio harveyi and infectious myonecrosis virus in Litopenaeus vannamei. Jurnal Akuakultur Indonesia. 13(1): 11-20.

Widigdo B. 2013. Bertambak Udang dengan Teknologi Biocrete. Jakarta (ID): Kompas.

Wyk PV, Scarpa J. 1999. Water Quality Requirements and Management. Florida (US): Harbor Branch Oceanographic Institution.

Wulandari T, Widyorini NP, Wahyu P. 2015. The relationship between water quality management and organic matter $\mathrm{NO}_{2}$ and $\mathrm{NH}_{3}$ in the cultivation of vaname shrimp (Litopeneus vannamei) in Keburuhan Purworejo Village. Diponegoro Journal of Maquares. 4(3): 42-48.

Yunita M, Hendrawan Y, Yulianingsih R, Keteknikan J. 2015. Microbiological quantitative analysis of Garuda Indonesia's aviation food (Aerofood ACS) based on TPC (Total Plate Count) with the Pour Plate method. Jurnal Keteknikan Pertanian Tropis Dan Biosistem. 3(3): 237-248.

Zhihong Z, Aweya1 JJ, Wang F, Yao D, Lun J, Li S, Ma H, Zhang Y. 2018. Acute Hepatopancreatic Necrosis Disease (AHPND) related microRNAs in Litopenaeus vannamei infected with AHPND-causing strain of Vibrio parahaemolyticus. BMC Genomics. 19(335): 1-11. 